\title{
THE POLITICAL IMAGERY IN THE MEDIA
}

Nowadays, the world is really hectic about the word that can be hypnotizing the society, it called "imagery". Image is belief as everything and able to change the direction or person's view on something that was never be anything. Something or someone that was nothing, suddenly can be more worth within media action. That is why called the craziness of media, as the way to construct something to be greater.

The political imagery in the study of postmodernism called simulacra, a word popularized by Jean Baudrillard. An episode of a pseudo-reality of mass-produced through a global communication media form and constructed the reality becomes seem real and consist the truth. The mistakes or untruth that broadcasted or played repeatedly it will makes the viewers believe that is true. This is the game of media and especially the social media (internet) that can take hand of television in process of construction society's minds.

Might be there are people who are aware, but there are many of people that not aware too about political imagery. Information that was passing at high speed that causing people don't have enough opportunities to assess the truth. The construction process is running such as massive lead in the end people will get caught up in false information. The things that happen it will not educating the nation but it will become misdirection and deception.

Almost everyday we presented with a variety of legal events that are packed in many ways, but unfortunately the media nowadays is not neutral enough. The media will not be a tool or a pillar of democracy but the tool for showing that the media itself was siding in one or other side. Coverage lopsided, with obsecure events or provide innacurate information, causing the mind direction of people is changing. The murder case of Wayan Mirna Shalihin is one of the clear example of this political imagery.

Television viewers and social media users was confused with media coverage tended to defend one of the parties and many question was rising who is the media owned by? The perpetrator and its advocate or the victim?. Then where is the role of law enforcement. The war of words, pictures, memes, and also more capable of making viewers and users of social confuse of the truth of these events.

Media is able to change everything, but everything don't be depends on the media, especially now some media is not neutral enough. As a smart citizen, we should not trust the information that is presented through the television or social media, and don't be provocated by this kind of political imagery. Actually, the information cultured society was hoping that we can be use the critical thinking for all information that we accepted, not just believe easily about what media gives and presented. Our critical mindset is one of the way to another truth that certainly might be different with the truth that media form for the viewers.

Purwokerto, May 2016

Editor in Chief, 